\title{
ТОЖДЕСТВО ИСКА О ПРИВЛЕЧЕНИИ К СУБСИДИАРНОЙ ОТВЕТСТВЕННОСТИ В ДЕЛЕ О БАНКРОТСТВЕ И ГРАЖДАНСКОГО ИСКА О ВОЗМЕЩЕНИИ ВРЕДА В УГОЛОВНОМ ДЕЛЕ
}

\section{IDENTITY OF A CLAIM FOR SUBSIDIARY LIABILITY IN A BANKRUPTCY CASE AND A CIVIL CLAIM FOR DAMAGES IN A CRIMINAL CASE}

A. Alfimova

Summary. Taking into account the low percentage of satisfaction of creditors' claims in bankruptcy cases - they receive nothing in $60 \%$ of cases - there is a tendency to use as many methods as possible to protect the interests of creditors, including by bringing persons controlling the debtor to various types of liability. The number of applications filed for bringing to subsidiary liability is growing every year, and in 2020 amounted to more than 6.6 thousand, of which about $40 \%$ were satisfied and about 3.2 thousand controlling persons were prosecuted to subsidiary liability. In such conditions, an actual issue is the correspondence of different types of liability for the same violations and the prevention of double prosecution.

The purpose of this study is to resolve the issue of the identity of a claim for bringing to subsidiary liability in a bankruptcy case and a civil claim for damage caused by a crime in a criminal case.

There are both general scientific methods, such as logical, systemic, structural-functional, statistical, and special methods of legal science, such as formal dogmatic, comparative legal, technical and legal to achieve the above purpose.

As a result, the nature of subsidiary liability and liability in the form of compensation for harm caused by a crime was determined, the elements of the above claims were identified and compared.

Keywords: identity of claims; bankruptcy; subsidiary liability; civil claim in a criminal case.
Алфимова Александра Сергеевна

МГЮА им. О.Е. Кутафина; практикующий юрист, старший юрист практики реструктуризации и банкротства Parallel Legal (OOO «ЛигалПараллель»),

2. Москва

alf.aleksandra@yandex.ru

Аннотация. С учетом низкого процента удовлетворения требований кредиторов в делах о банкротстве - они не получают ничего в $60 \%$ случаев наблюдается тенденция применения как можно большего количества способов защиты их интересов, в том числе путем привлечения контролирующих должника лиц к различным видам ответственности. Число поданных заявлений о привлечении к субсидиарной ответственности растет с каждым годом, и в 2020 году составило более 6,6 тысяч, из которых были удовлетворены около 40\% и к ответственности привлечено около 3,2 тысяч контролирующих лиц. В таких условиях актуальным вопросом является соотношение различных видов ответственности за одни и те же нарушения и предотвращение двойного привлечения к ответственности.

Цель настоящего исследования заключается в том, чтобы решить вопрос о тождестве иска о привлечении к субсидиарной ответственности в рамках дела о банкротстве и гражданского иска о возмещении вреда, причиненного преступлением, в уголовном деле.

В рамках исследования для достижения поставленной выше цели применялись как общенаучные методы, такие как логический, системный, структурно-функциональный, статистический, так и специальные методы юридической науки, такие как формально-догматический, сравнительно-правовой, технико-юридический.

В результате проведенного исследования была определена природа субсидиарной ответственности и ответственности в виде возмещения вреда, причиненного преступлением, были установлены элементы вышеназванных исков и проведено их сравнение.

Ключевые слова: тождество исков; банкротство; субсидиарная ответственность; гражданский иск в уголовном деле.

тождества заявленных к контролирующему лицу требований, которые пока в недостаточной степени проработаны в теории и на практике.

С учетом увеличивающегося количества уголовных дел, которые сегодня стали частыми спутниками дел о банкротстве, и повального привлечения контролирующих лиц к субсидиарной ответственности актуальным 
представляется вопрос о тождестве иска о возмещении вреда в рамках уголовного дела и иска о привлечении к субсидиарной ответственности. Например, генеральный директор привлекается к уголовной ответственности за неуплату должником налогов по статье 199 УК РФ [30]. Налоговый орган в свою очередь включается в реестр требований кредиторов должника на сумму неуплаченных налогов и требует привлечь того же директора к субсидиарной ответственности в размере непогашенных требований кредиторов по ст. 61.11 Закона о банкротстве [31]. Также предъявляется гражданский иск о возмещении ущерба в уголовном деле. Возникает ли в данном случае тождество иска о привлечении к субсидиарной ответственности с гражданским иском в уголовном деле или нет?

\section{Понятие тожАества исков}

При рассмотрении проблемы тождества исков мы будет исходить из внешнего тождества исков, то есть совпадения элементов двух предъявленных исков. Относительно элементов иска в науке российского процессуального права до сих пор продолжаются дискуссии. Одни ученые придерживаются подхода Гурвича М.А. и выделяют предмет, основание и содержание иска [6]. Другие авторы поддерживают позицию Осокиной Г.Л., согласно которой элементами являются предмет, основание и стороны [18]. Но наиболее признанной является точка зрения, согласно которой элементами иска являются предмет и основание [7].

Под предметом иска в теории гражданского процесса понимается либо в широком смысле спорное гражданско-правовое отношение [6], либо в узком смысле материально-правовое требование истца к ответчику [7]. Последняя точка зрения находит свое отражение в судебной практике [25]. Например, в пункте 3 Постановления Пленума ВАС РФ от 31.10.1996 № 13 «О применении АПК РФ при рассмотрении дел в суде первой инстанции» установлено, что изменение предмета иска означает изменение материально-правового требования истца к ответчику [24].

Относительно основания иска разворачивается ещё более жаркая дискуссия, потому что в отличие от предмета основание иска имеет принципиальное значение в англо-саксонской правовой системе и во многих странах континентальной Европы, следовательно, имеется обширный научный и практический опыт зарубежных коллег. В основание иска традиционно включаются юридические факты, на основании которых предъявляется иск [6]. Включение в основание иска правовой квалификации указанных фактов является дискуссионным и признается не всеми учёными. В пункте 3 вышеупомянутого Постановления Пленума ВАС РФ от 31.10.1996
№ 13 под изменением основания иска понимается изменение обстоятельств, на которых истец основывает свое требование к ответчику [24]. Таким образом, правоприменительная практика исходит из фактического подхода к основанию иска.

Для того чтобы выявить наличие или отсутствие тождества между иском о привлечении к субсидиарной ответственности и иском о возмещении вреда, причиненного преступлением, необходимо разобраться в природе этих двух видов ответственности.

\section{Прирома субси иарной ответственности}

На сегодняшний день в науке и правоприменительной практике имеется три основных подхода к природе субсидиарной ответственности.

1. Субсидиарная ответственность - дополнительная ответственность. Согласно общему правилу, закрепленному в пункте 1 статьи 48 ГК РФ [5], обособленное юридическое лицо самостоятельно несет ответственность перед кредиторами. В статье 399 ГК РФ, посвященной субсидиарной ответственности, установлено, что в силу закона или договора лицо может быть обязано возместить вместо основного должника причиненный им вред. В свою очередь специальными нормами главы III.2 Закона о банкротстве установлена субсидиарная ответственность контролирующих лиц - экстраординарный механизм возмещения потерь кредиторов должника-банкрота [23].

Точка зрения о дополнительной природе субсидиарной ответственности не получила широкого распространения ни в доктрине, ни в судебной практике. В судебной практике окончательный отказ от неё произошел после выхода Определения Верховного Суда РФ от 16.12.2019 в рамках дела о банкротстве ООО «Амурский нефтепродукт». Верховный Суд РФ, пресекая квалификацию субсидиарной ответственности по статье 399 ГК РФ, указал, что «статьей 399 ГК РФ урегулирована ответственность дополнительная, в то время как субсидиарная ответственность, предусмотренная Законом о банкротстве, является самостоятельной (основной) ответственностью контролирующего лица за нарушение обязанности действовать добросовестно и разумно по отношению к кредиторам подконтрольного лица» [16].

2. Субсидиарная ответственность - особый вид ответственности, осуществляемый путем «снятия корпоративного покрова». Такая квалификация характерна для англо-американского правопорядка и, по сути, в рамках конструирования субсидиарной ответствен- 
ности мы ориентировались именно на эту модель. За рубежом «снятие корпоративной вуали» направлено на «защиту от злоупотреблений принципом ограниченной ответственности участников по долгам компании» [9]. В иностранных правопорядках речь идет именно о защите от гражданско-правовых злоупотреблений, для иных видов злоупотреблений предусмотрены административная и/или уголовная ответственности.

В нашей же действительности субсидиарная ответственность используется как универсальный инструмент борьбы со всеми возможными, в том числе публично-правовыми нарушениями [3]. Как отмечает Мифтахутдинов Р.Т., «пока что в наших реалиях общий уровень культуры ведения бизнеса, построения экономических связей достаточно невысок, и если сразу начать бороться со всеми злоупотреблениями...с помощью уголовно-правовой юрисдикции, то бизнесом уже некому будет заниматься» [12]. Таким образом, сегодня российская модель субсидиарной ответственности не в полной мере соответствует доктрине «снятия корпоративного покрова».

3. Победившей на данный момент в российской судебной практике является позиция о деликтном характере субсидиарной ответственности. Она базируется на том, что субсидиарная ответственность наступает в связи с причинением вреда имущественным правам кредиторов подконтрольного лица. Следовательно, долг, возникший из субсидиарной ответственности, должен быть подчинен тому же правовому режиму, что и иные долги, связанные с возмещением вреда имуществу участников оборота согласно статье 1064 ГК РФ [4].

Верховный Суд РФ последовательно проводит указанную точку зрения как в Постановлении Пленума Верховного Суда РФ от 21.12.2017 № 53 [23], так и в отдельных определениях и обзорах судебной практики [13]. Верховный Суд РФ отмечает, что требование о привлечении к субсидиарной ответственности «по сути опосредует типизированный иск о возмещении причиненного вреда, возникшего у кредиторов в связи с доведением основного должника до банкротства» [15].

Именно исходя из деликтной природы субсидиарной ответственности в деле о банкротстве ООО «Дальняя степь» иск о привлечении к субсидиарной ответственности был квалифицирован как групповой косвенный иск о возмещении вреда [17]. А в деле о банкротстве ООО «Амурский нефтепродукт» Верховный Суд РФ разрешил наследование обязательств из субсидиарной ответственности [16].

Среди особенностей данного иска Верховный Суд РФ выделяет его специальное применение, упро- щенный процесс доказывания, правила об исковой давности и размер ответственности. При этом как отмечает Верховный Суд РФ, «размер ответственности сам по себе правовую природу требований никак не характеризует» [15]. Такая оговорка важна, так как в ключе квалификации субсидиарной ответственности как деликтной наиболее интересен именно её размер, который лишь опосредованно равен размеру причиненного вреда. Опосредованно - потому что лицо, привлекаемое к субсидиарной ответственности, может причинить вред, совершив, например, две сделки, которые вывели из имущественной массы должника условно 10 рублей, и привели (или все-таки не привели?) к банкротству с общим размером реестра требований кредиторов в 100 рублей. Получается, что прямой вред равен 10 рублям, однако, лицо привлекается к ответственности и становится обязанным компенсировать кредиторам 100 рублей.

Частично эту проблему на теоритическом уровне решает пункт 20 Постановлении Пленума Верховного Суда РФ от 21.12.2017 № 53 [23], где установлено, что в случае, когда причиненный контролирующими лицами вред исходя из разумных ожиданий не должен был привести к объективному банкротству должника, такие лица обязаны компенсировать возникшие по их вине убытки в размере, определяемом по правилам статей 15, 393 ГК РФ. При этом с сожалением приходится констатировать, что на практике этот подход применяется не так часто [14], в основном суды не разбираются, повлекли ли действия лица банкротство предприятия, и привлекают всех лиц к субсидиарной ответственности на весь непогашенный реестр требований кредиторов.

\section{Природа ответственности \\ в ви е возмешения вреАа, \\ причиненного преступлением}

В отличие от субсидиарной ответственности здесь не возникает споров относительно природы ответственности за вред, причиненный преступлением она носит деликтный характер.

Уголовно-процессуальное законодательство [29] не содержит определения гражданского иска. В доктрине он определяется как требование физического или юридического лица о возмещении имущественного ущерба и морального вреда, причиненного преступлением, к обвиняемому либо лицу, несущему материальную ответственность за действия обвиняемого, заявленные при производстве по уголовному делу [2]. При этом нужно учитывать, что не всегда гражданский иск направлен на защиту частных интересов, в налоговых преступлениях, например, он направлен на защиту публичных интересов. 
Возможность предъявления гражданского иска в рамках уголовного дела обусловлена, на наш взгляд, прежде всего процессуальной экономией. Некоторые авторы также обращают внимание на необходимость государству реагировать не только на нарушение публичных, но и на нарушение частных интересов, а также на то, что «наказание рублем» гораздо лучше предотвращает последующие преступления [19].

Многие ученые и практикующие юристы с сожалением констатируют, что пока институт гражданского иска в уголовном деле в России работает неэффективно [28]. При этом общеприменимых механизмов компенсации вреда, причиненного преступлением, со стороны государства в пользу потерпевших в российском законодательстве в отличие от зарубежного не предусмотрено [8].

На контрасте с иными потерпевшими выгодно выделяется государство, которое в рамках налоговых преступлений достаточно успешно компенсирует вред путем предъявления гражданского иска в уголовном деле. Так, в недавнем Постановлении по «делу Ахмадеевой» Конституционный Суд РФ подчеркнул возможность налоговых органов обращаться с иском о возмещении вреда на основании статьи 1064 ГК РФ, причиненного налоговым преступлением: «...отношения между публично-правовым образованием и физическим лицом, совершившим налоговое преступление, по поводу возмещения вреда, причиненного бюджету публично-правового образования в результате неуплаты налогов организацией-налогоплательщиком, являются не налогово-правовыми, а гражданско-правовыми. При предъявлении такого рода исков органы ФНС РФ выступают, по сути, в качестве представителя интересов соответствующего публично-правового образования, лишившегося имущества в размере налоговых платежей, которые не поступили в бюджет в результате неправомерных действий физического лица» [22].

\section{ТожАество иска о привлечении \\ к субсиАиарной ответственности в $\Delta$ еле о банкротстве и граж $а$ анского иска о возмешении вреАа \\ в уголовном $\triangle$ еле}

Итак, определив критерии для сравнения (элементы иска), попробуем ответить на изначальный вопрос об их тождестве. Напомню наш пример: генеральный директор привлекается к уголовной ответственности за неуплату должником налогов. Налоговый орган, включенный в реестр требований кредиторов должника на сумму неуплаченных налогов, требует одновременно привлечь директора к субсидиарной ответственности в деле о банкротстве и удовлетворить гражданский иск о возмещении ущерба в уголовном деле.

Предмет иска о привлечении к субсидиарной ответственности - это требование о возмещении вреда кредиторам, причиненного действиями генерального директора по доведению должника до банкротства. Предмет гражданского иска в уголовном деле - это требование ФНС РФ о возмещении вреда, причиненного преступлением генерального директора по уклонению от уплаты налогов. Таким образом, предмет иска можно считать совпадающим только в части возмещения вреда государству (в лице ФНС РФ) на сумму неуплаченных налогов. Иными словами, предмет гражданского иска в уголовном деле уже, чем предмет иска о привлечении к субсидиарной ответственности в деле о банкротстве.

Основания исков в упрощенном виде представляют следующее. Фактическое основание иска о привлечении к субсидиарной ответственности - действия директора по доведению должника до банкротства, в том числе по неуплате налогов. Юридическое основание нормы главы III.2 Закона о банкротстве и статьи 1064 ГК РФ. Фактическое основание гражданского иска в уголовном деле - преступные действия директора по неуплате налогов. Юридическое основание - нормы статей 199 УК РФ и статьи 1064 ГК РФ. Таким образом, фактическое и юридическое основания двух исков пересекаются, но не совпадают целиком.

Если мы говорим о сторонах двух этих исков, то нужно учитывать, что иск о субсидиарной ответственности - это косвенный групповой иск, который заявляется налоговым органом в интересах всех кредиторов должника. Гражданский иск в уголовном деле в свою очередь прямой иск налогового органа к директору о возмещении вреда, причиненного одному кредитору. Таким образом, имеется совпадение материального истца в части налогового органа, и ответчик - генеральный директор - также совпадает.

Из приведённого выше анализа напрашивается вывод, что в части требований налогового органа о возмещении вреда, причиненного действиями по неуплате налогов, иски тождественны. К аналогичному выводу приходит и Верховный Суд РФ в Определении от 03.07.2020 по делу о банкротстве ООО «ДИС» [15], а также некоторые нижестоящие суды [20].

Вывод Верховного Суда РФ о тождестве исков в деле о банкротстве ООО «ДИС» основан на следующих предпосылках:

1. как предмет, так и основание предъявленного в рамках настоящего обособленного спора 
требования [о привлечении к субсидиарной ответственности] и рассмотренного судом общей юрисдикции гражданского иска [в рамках уголовного дела] фактически совпадают;

2. при определении соотношения этих требований необходимо исходить из их зачетного характера по отношению друг к другу (пункт 1 статьи 6, абзац первый пункта 1 статьи 394 ГК РФ);

3. при определении вопроса, совпадают ли стороны, необходимо исходить из того, что требование о привлечении контролирующих лиц к субсидиарной ответственности является косвенным, заявляемым в интересах кредиторов основного должника, выступающих фактически материальными истцами, таким образом, фигуры материальных истцов в части уполномоченного органа также совпадают;

4. заявив прямой иск к руководителю должника о возмещении причиненного вреда вне рамок дела о банкротстве, уполномоченный орган фактически выбрал способ распоряжения частью принадлежащего ему требования;

5. наличие потенциальной возможности удовлетворить свое требование с помощью иного процессуального механизма само по себе признака тождественности второго иска не устраняет.

Руководствуясь изложенными выше аргументами, Верховный Суд РФ в рамках дела о банкротстве ООО «ДИС» прекратил производство по привлечению к субсидиарной ответственности директора в части взыскания суммы, на которую был удовлетворен гражданский иск в уголовном деле.

Рассмотренный Верховным Судом РФ кейс является нетипичным и даже можно сказать идеальным по нескольким причинам. Во-первых, уголовное дело и гражданский иск в нем были рассмотрены очень быстро и предшествовали разрешению требования о привлечении к субсидиарной ответственности. На практике последовательность обычно обратная, так как, несмотря на затянутость дел о банкротстве, уголовные дела расследуются и рассматриваются гораздо дольше.
Во-вторых, третью очередь реестра требований кредиторов составляли почти целиком требования налогового органа. Такая ситуация встречается на практике, но чаще реестр требований кредиторов составляет целое множество требований различных лиц. В-третьих, к субсидиарной ответственности привлекался только генеральный директор, иные лица не привлекались. В условиях новых правил главы III.2 Закона о банкротстве и тренда на повальное привлечение всех контролирующих лиц к субсидиарной ответственности такая ситуация также является нетипичной.

В обособленном споре, рассмотренном Верховным Судом РФ, принятое им решение представляется логичным, обратное привело бы по сути к неосновательному обогащению уполномоченного органа. Однако, если мы пытаемся применить эту логику на иные более сложные и гораздо более часто встречающиеся на практике ситуации, то возникают проблемы и пробелы в логике. Например, как поступать, если к субсидиарной ответственности за действия по неуплате налогов привлекается не только директор, на и, предположим, его заместитель, а к уголовной ответственности только директор? Или в случае, если к банкротству привели не только действия, являющиеся составом преступления, но и иные действия? Можно ли применять эту логику в рамках банкротства группы компаний, когда, например, выгодоприобретатель имущества группы компаний привлекается многократно к субсидиарной ответственности в 10 делах о банкротстве компаний группы?

\section{Зак^ючение}

Позиция относительно тождества рассматриваемых исков, занятая Верховным Судом РФ в конкретном деле, направлена на защиту интересов контролирующего лица и реализацию конституционного принципа недопустимости многократного привлечения к ответственности за одни и те же действия [21]. Дальнейшее применение этой позиции будет зависеть от широты её толкования судами и распространения заданного Верховным Судом РФ тренда на менее формальный подход к тождеству исков.

\section{ЛИТЕРАТУРА}

1. Арбитражный процессуальный кодекс Российской Федерации от 24.07.2002 № 95-Ф3. Собрание законодательства РФ. 2002. № 30 (ред. от 08.12.2020);

2. Бубчикова М.В. Гражданский иск в уголовном процессе. Москва. Российский судья. 2015. № 9;

3. Горбашев И.В. 0 некоторых материально-правовых аспектах привлечения к субсидиарной ответственности в разъяснениях ВС РФ. Москва. Вестник гражданского права. 2018. № 4;

4. Гражданский кодекс Российской Федерации (часть вторая) от 26.01.1996 № 14-Ф3. Собрание законодательства РФ. 1996. № 5 (ред. от 09.03.2021);

5. Гражданский кодекс Российской Федерации (часть первая) от 30.11.1994 № 51-Ф3. Собрание законодательства РФ. 1994. № 32 (ред. от 09.03.2021)

6. Гурвич М.А. Учение об иске. Учебное пособие. Москва. 1981;

7. Добровольский А.А. Исковая форма защиты права (основные вопросы учения 06 иске). Москва. 1965; 
8. Дубровин В.В. Возмещение вреда, причиненного преступлением, путем компенсации со стороны государства (отечественный и зарубежный опыт). Москва. Международное уголовное право и международная юстиция. 2010. № 3;

9. Егоров А.В., Усачева К.А. Доктрина «снятия корпоративного покрова» как инструмент распределения рисков между участниками корпорации и иными субъектами оборота. Москва. Вестник гражданского права. 2014. № 1;

10. Единый федеральный реестр сведений о банкротстве. URL: https://bankrot.fedresurs.ru/?attempt=1 (дата обращения 06.05.2021);

11. Информационная система «Картотека арбитражных дел». URL: https://kad.arbitr.ru/ (дата обращения 06.05.2021);

12. Мифтахутдинов Р.Т. Пленум четко сказал, что субсидиарная ответственность применяется в исключительных случаях. Москва. Закон. 2018. № 7;

13. Обзор судебной практики Верховного Суда Российской Федерации № 4 (2020), утвержденный Президиумом Верховного Суда РФ 23.12.2020;

14. Определение Верховного Суда РФ от 08.04.2019 № 309-ЭС19-2667 по делу № А50-25597/2015, Определение Верховного Суда РФ от 28.01.2019 № 309ЭС17-12924(3) по делу № А50-8447/2015, Постановление Арбитражного суда Московского округа от 05.03.2020 № Ф05-24381/2019 по делу № А4119612/2016, Постановление Арбитражного суда Поволжского округа от 23.07.2020 № Ф06-45888/2019 по делу № А65-17406/2016, Постановление Арбитражного суда Северо-Западного округа по делу от 16.07.2020 по делу № A21-328/2016, Постановление Арбитражного суда Уральского округа от 30.07.2020 № Ф09-4350/20 по делу № А60-60872/2018;

15. Определение Судебной коллегии по экономическим спорам Верховного Суда Российской Федерации от 03.07.2020 № 305-ЭС19-17007(2) по делу № A40-203647/2015;

16. Определение Судебной коллегии по экономическим спорам Верховного Суда РФ от 16.12.2019 № 303-ЭС19-15056 по делу № А04-7886/2016;

17. Определение Судебной коллегии по экономическим спорам Верховного Суда Российской Федерации от 06.08.2018 № 308-ЭС17-6757(2,3) по делу № A22-941/2006;

18. Осокина Г.Л. Иск (теория и практика). Москва. 2000;

19. Оськина И., Лупу А. Гражданский иск в уголовном процессе. Москва. ЭЖ-Юрист. 2014. № 11;

20. Постановление Арбитражного суда Поволжского округа от 29.06.2020 № Ф06-52283/2019 по делу № А12-15649/2019, Постановление Тринадцатого арбитражного апелляционного суда от 15.12.2020 № 13АП-3559/2020 по делу № А56-94386/2018, Постановление Пятнадцатого арбитражного апелляционного суда от 30.03.2021 № 15АП-794/2021 по делу № А53-1203/2016;

21. Постановление Конституционного Суда РФ от 04.02.2019 № 8-П, Постановление Конституционного Суда РФ от 15.07.1999 № 11-П, Постановление Президиума ВАС РФ от 15.04.2014 № 19440/13, Определение Судебной коллегии по экономическим спорам Верховного Суда РФ от 16.11 .2020 № 305-ЭС20-11900 по делу № A40-189753/2019, Кассационное определение Судебной коллегии по административным делам Верховного Суда РФ от 11.09.2019 № 51-КА19-10;

22. Постановление Конституционного Суда РФ от 08.12.2017 № 39-П «По делу о проверке конституционности положений статей 15 , 1064 и $1068 Г K ~ Р Ф$, подпункта 14 пункта 1 статьи 31 НК РФ, статьи 199.2 УК РФ и части первой статьи 54 УПК РФ в связи с жалобами граждан Г.Г. Ахмадеевой, С.И. Лысяка и А.Н. Сергеева». Российская газета. № 291. 2017;

23. Постановление Пленума Верховного Суда РФ от 21.12.2017 № 53 «0 некоторых вопросах, связанных с привлечением контролирующих должника лиц к ответственности при банкротстве». Российская газета. № 297. 2017 (ред. от 21.12.2017);

24. Постановление Пленума ВАС РФ от 31.10.1996 № 13 «0 применении АПК РФ при рассмотрении дел в суде первой инстанции». Российская газета. № 227. 1996 (ред. от 09.07.1996);

25. Постановление Президиума ВАС РФ от 27.07.2004 № 2353/04 по делу № A60-14530/03-С4, Постановление Верховного Суда РФ от 04.07.2016 № 305АД16-8893 по делу № А40-134966/2015;

26. Справочно-правовая система «КонсультантПлюс». URL: http://www.consultant.ru/Online/ (дата обращения 06.05.2021);

27. Суворов Е.Д. К вопросу о правовой природе субсидиарной ответственности по обязательствам несостоятельного должника за доведение до банкротства. Законы России: опыт, анализ, практика. Москва. 2018. № 7;

28. Сушина Т.Е. Современное состояние и перспективы развития гражданского иска в уголовном процессе. Москва. Lex russica. 2019. № 3;

29. Уголовно-процессуальный кодекс Российской Федерации от 18.12.2001 № 174-Ф3. Собрание законодательства РФ. 2001. № 52 (ред. 0т 05.04.2021);

30. Уголовный кодекс Российской Федерации от 13.06.1996 № 63-Ф3. Собрание законодательства РФ. 1996. № 25 (ред. от 05.04.2021);

31. Федеральный закон от 26.10.2002 № 127-Ф3 «0 несостоятельности (банкротстве)». Собрание законодательства РФ. 2002. № 43 (ред. от 30.12.2020).

( Алфимова Александра Сергеевна ( alf.aleksandra@yandex.ru ).

Журнал «Современная наука: актуальные проблемы теории и практики» 